\title{
Succession of mycorrhizae: a matter of tree age or stand age?
}

\author{
D. Blasius and F. Oberwinkler
}

Institut für Botanik, Spezielle BotanikMykologie, Universität Tübingen Auf der Morgenstelle 1 , D-7400 Tübingen, F.R.G.

\section{Introduction}

There is a considerable amount of published evidence to support the view that a succession of mycorrhizae occurs during the development of first-rotation forest plantations (Dighton and Mason, 1985; Dighton et al., 1986; Haas, 1979; Ricek, 1981). As a consequence, 'early stage' and 'late stage' fungi were distinguished, thus reflecting the observations that initial colonizers of tree roots, such as Laccaria and Hebeloma species, are followed or replaced 6-10 yr after planting by, e.g., Lactarius, Amanita and Russula species (Mason et al., 1982; Last et al., 1983). In contrast to the ability to form mycorrhizae under axenic conditions, 'late stage' fungi did not infect seedlings in non-sterile soils after afforestation of farmland and in soil cores with fungal inoculum (Mason et al., 1983; Deacon et al., 1983).

The physiological status of trees of different ages as well as changes of the substrate and nutrient resources during stand development are considered to be the most relevant factors to explain the temporal and spatial succession phenomena
(Dighton and Mason, 1985). However, tree age and substrate change simultaneously after planting, and it is difficult to decide which factor may be more important. Studies in established stands with nearly constant soil conditions and naturally regenerated trees should provide information to answer this question.

\section{Materials and Methods}

Samples of mycorrhizae were taken from 2 stands of Picea abies (L.) Karst. in the Black Forest near Freudenstadt. Stand and site descriptions have already been given by Blasius et al. (1985).

About $1501 \mathrm{yr}$ old seedlings and about 100 8-10 yr old trees were removed entirely from the soil and stored at $4^{\circ} \mathrm{C}$. Mycorrhizae were dissected from the soil in running water and were washed further in distilled water.

Mycorrhizal types were selected and photographed under a stereoscopic dissecting microscope. Afterwards, they were fixed in glutaraldehyde with cacodylate buffer. Embedding was carried out with ERL (Spurr, 1969) after postfixation with osmium tetroxide and en bloc staining with uranyl acetate. Serial longitudinal and even transverse semi-thin sections $(0.5 \mu \mathrm{m})$ for light microscopy were cut with 
Table I. Characterization of the mycorrhizae.

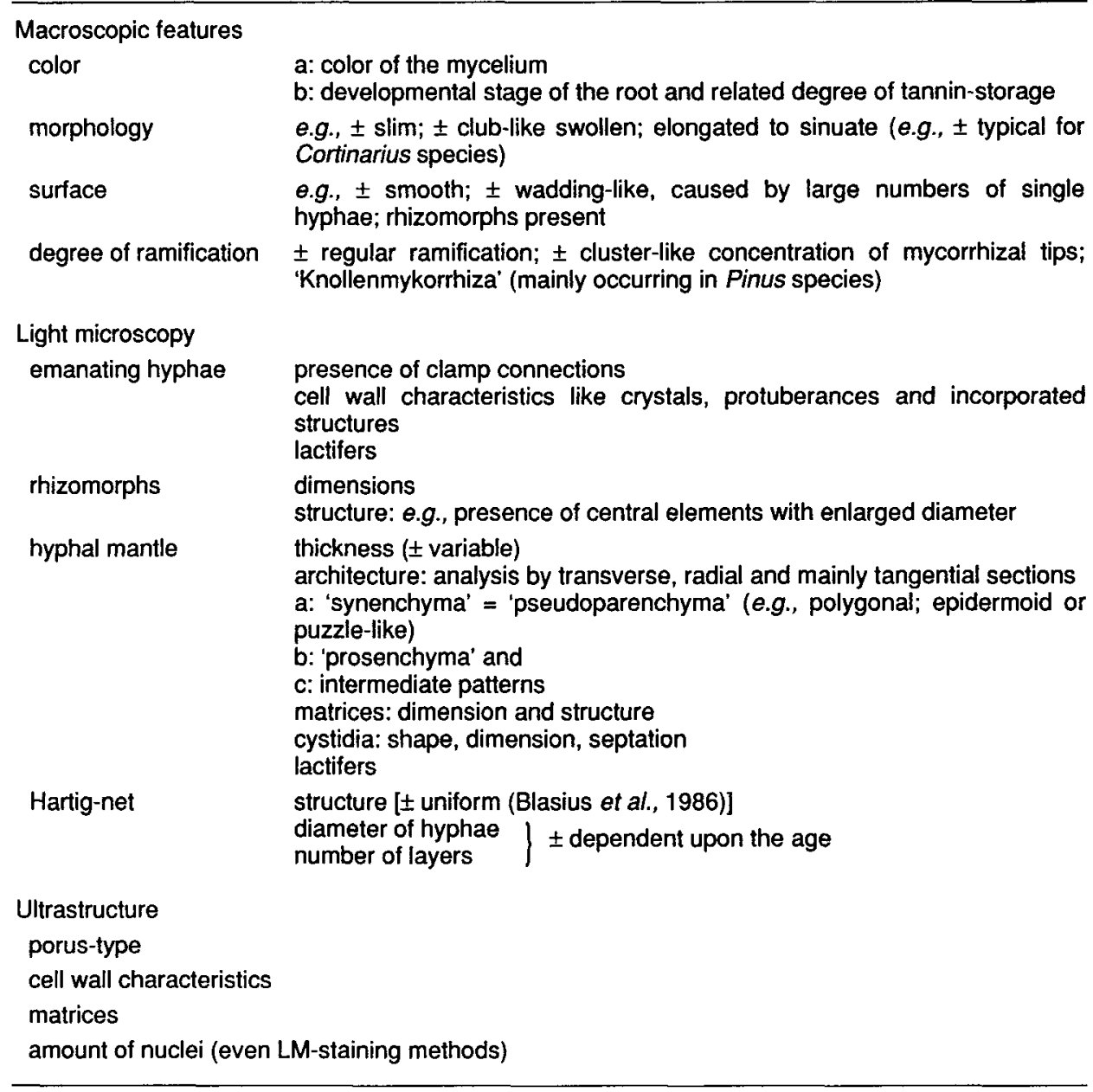

glass knives and stained with new fuchsin-crystal violet. For electron microscopy ultra-thin sections $(80-100 \mathrm{~nm})$ were cut with a diamond knife and stained with lead citrate.

Fresh material of each type was investigated in order to detect alterations of structural features during the fixation process.

The distribution of the mycorrhizal types in relation to tree age was tested. A statistical quantification was not carried out because of methodological difficulties.

\section{Results}

Characterization of the mycorrhizae

17 mycorrhizal types ( 3 ascomycetes and 14 basidiomycetes) were distinguished by the features given in the above, annotated checklist (Table I). 
Distribution of the types in relation to tree age

On both stands, all types were detected on seedlings as well as on 8-10 yr old trees. One Lactarius-type was very abundant on seedlings and was recognized by the presence of lactifers in the mantle. Furthermore, Russula ochroleuca (Pers.) Fr. (Agerer, 1986) was found to form mycorrhizae with seedlings.

\section{Discussion and Conclusion}

The investigations revealed, that no differences in the occurrence of mycorrhizal types in relation to tree age were apparent. The distribution should be different if succession depends upon the tree age. Typical 'late stage' fungi, like Lactarius and Russula species, seem to be able to form mycorrhizae with seedlings in established ecosystems. This observation is concordant with findings of Thomas et al. (1983) who detected Lactarius rufus (Scop.) Fr. and $R$. ochroleuca on naturally regenerating seedlings of Picea sitchensis (Bog.) Carr. These observations confirm the view that succession of mycorrhizae after afforestation of farmland is mainly caused by changes of the substrate and nutrient resources. Dighton and Mason (1985) discussed the changes from $r$ - to $\mathrm{K}$-strategies during stand development as a complex of factors which reflect the adaptation of different species to varying environmental conditions.

However, the interpretation is complicated by the fact that mycorrhizal fungi likely are in contact with both mature trees and seedlings of stands with natural regeneration. Intra- and interspecific transfer of carbon and nutrients between hosts has been proven (e.g., Read et al., 1985;
Woods and Brock, 1964). By this, the carbon demand of late stage fungi which form mycorrhizae with seedlings may be satisfied by older trees. Fleming (1984) discussed the passible role of mature trees as a food base for 'late stage' fungi which colonize seedlings.

Studies on the succession of mycorrhizae after afforestation of areas which were recently deforested should provide further information about the physiological role of substrate or tree age in relation to succession phenomena. Ricek (1981) found differences in the succession of fruit bodies after afforestation of meadows and clear cut forest stands. Fungal species, which appeared late in the succession chain after afforestation of meadows, were observed to be early mycorrhizae formers when afforesting previous forest soils. The author concludes that these species, representing 'late stage' fungi, may have persisted saprophytically and were able to infect seedlings after planting.

\section{References}

Agerer R. (1986) Studies on ectomycorrhizae III. Mycorrhizae formed by four species in the genera Lactarius and Russula on spruce. Mycotaxon 27, 1-59

Blasius D., Kottke I. \& Oberwinkler F. (1985) Zur bewertung der güte von fichtenwurzeln geschädigter bestände. Forstwiss. Centralbi. 104, 318-325

Blasius D., Feil W., Kottke I. \& Oberwinkler F. (1986) Hartig net structure and formation in fully ensheathed ectomycorrhizas. Nord. J. Bot. 6, 837-842

Deacon J.W., Donaldson S.J. \& Last F.T. (1983) Sequences and interactions of mycorrhizal fungi on birch. Flant Soil 71, 257-262

Dighton J. \& Mason P.A. (1985) Mycorrhizal dynamics during forest tree development. in: Developmental Biology of Higher Fungi. (Moore D., et al., eds.) British Mycological Society Symposium 10, Cambridge University Press, Cambridge, pp. 117-139 
Dighton J., Poskitt J.M. \& Howard D.M. (1986) Changes in occurrence of basidiomycete fruit bodies during forest stand development with specific reference to mycorrhizal species. Trans. Br. Mycol. Soc. 87, 163-171

Fleming L.V. (1984) Effects of soil trenching and coring on the formation of ectomycorrhizas on birch seedlings grown around mature trees. New Phytol. 98, 143-153

Haas H. (1979) Die pilzflora in rotfäulebefallenen fichten-durchforstungs-beständen auf der schwäbischen alb. Mitt. Ver. Forstl. Standortskunde Forstpflanzenzüchtung 27, 6-25

Last F.T., Mason P.A., Wilson J. \& Deacon J.W. (1983) Fine roots and sheathing mycorrhizas: their formation, function and dynamics. Plant Soil 71, 9-2.1

Mason P.A., Last F.T., Pelham J. \& Ingleby K. (1982) Ecology of some fungi associated with an ageing stand of birches (Betula pendula and B. pubescens). For. Ecol. Manage. 4, 19-39

Mason P.A., Wilson J., Last F.T. \& Walker C. (1983) The concept of succession in relation to the spread of sheathing mycorrhizal fungi on inoculated tree seedlings growing in unsterile soils. Plant Soil 71, 247-256

Read D.J., Francis R. \& Finlay R.D. (1985) Mycorrhizal mycelia and nutrient cycling in plant communities. In: Ecological Interactions in Soil. (Fitter A.H. et al., eds.), Blackwell Scientific Publications, Oxford, pp. 193-217

Ricek E.W. (1981) Die pilzgesellschaften heranwachsender fichtenbestände auf ehemaligen wiesenflächen. Z. Mykol. 47, 123-148

Spurr A. (1969) A low-viscosity epoxy resin embedding medium for electron microscopy. $J$. Ultrastruct. Res. 26, 31-43

Thomas G.W., Rogers D. \& Jackson R.M. (1983) Changes in the mycorrhizal status of Sitka spruce following outplanting. Plant Soil $71,319 \cdot 323$

Woods F.W. \& Brocks K. (1984) Interspecific transfer of $\mathrm{Ca}-45$ and $\mathrm{P}-32$ by root systems. Ecology 45, 886-889 